\title{
STRATEGI PERANCANGAN DENGAN PENERAPAN RAGAM HIAS SULUR GELUNG PADA PRODUK KRIYA UNTUK PASAR GLOBAL
}

\author{
Agung Wicaksono dan Budi Hartono *)
}

\begin{abstract}
ABSTRAK
Ragam hias sulur gelung banyak tersebar di bangunan candi dan masjid. Konsep dasarnya adalah penciptaan alam semesta menurut perspektif agama Hindu. Namun pada masjid peran dan konsep ragam hias ini berubah, disesuaikan dengan kaidah-kaidah dalam agama Islam. Warisan budaya ini perlu dilestarikan dan dikembangkan. Metode dan strategi penegmbangan diperlukan untuk keperluan tersebut. Strategi perancangan adalah urutan langkah-langkah yang disiapkan dan metode perancangan adalah cara yang digunakan pada perancangan. Ini diperlukan kaidah-kaidah estetika dalam senirupa untuk optimalisasi pencapaiannya.
\end{abstract}

Kata kunci : sulur gelung, strategi perancangan,kriya, pasar global

\section{PENDAHULUAN}

Merunut

sejarah proses penciptaan kriya masa lalu (tradisional), khususnya di Jawa, jarang sekali atau bahkan tidak pernah ada dokumendokumen proses perancangannya. Produk atau karya kriya dibuat secara bersamasama proses perancangan dan perwujudannya. Empu-empu pembuat keris memiliki "kepandaian" membuat karya yang telah menyatu dalam dirinya. Seolah-olah mereka menciptakan karya tersebut secara spontan tanpa proses perancangan. Metode ini banyak dilakukan oleh kriyawan-kriyawan dari dulu kala, oleh karena itu jarang ditemui literatur-literatur proses penciptaan kriya.

Meskipun proses penciptaan kriya jarang diketahui tahap perancangannya tetapi karya kriya tradisi memiliki pola-pola yang hampir mirip antara satu dengan lainnya. Perbedaanya terdapat pada detail teknik produksi, bahan, dan penggayaannya. Christopher Jones (1979:19) menyebutkan bahwa terdapat beberapa ciri khas pada proses pembuatan produk kriya tradisional antara lain : (1) kriyawan tidak atau jarang membuat desain dalam bentuk gambar perancangan dan sering tidak dapat menjelaskan keputusan-keputusan yang diambil selama proses penciptaannya, (2) pencapaian bentuk produk dilakukan dengan metode coba-coba (trial and error) dalam kurun waktu relatif lama, dan (3) karya kriya memiliki "genetic coding" yang dapat dijadikan data untuk melihat proses evolusi bentuknya.

Jika dilihat pada artefak-artefak kriya masa lalu yang salah satunya terdapat

\footnotetext{
* Agung Wicaksono, (agung_w@yahoo.com), Budi Hartono (baworbudi@gmail.com) Staf Pengajar di Jurusan Kriya Fakultas Seni Rupa Institut Seni Indonesia Yogyakarta
} 
pada ornamen-ornamen candi, maka dapat terlihat kepiawaian kriyawan dalam penciptaan karyanya. Pada artefak tersebut dapat dipelajari dengan seksama metode pembuatannya dengan konteks sosial budaya yang terjadi pada masyarakat pendukungnya. Kajian yang dilakukan untuk melihat artefak kriya dengan beberapa perspektif pendekatan diperlukan untuk memahami kompleksitas proses penciptaanya. Biasanya kajian estetika pada proses penciptaan kriya akan dikaitkan masalah bentuk, fungsi, dan makna. Kajian lain yang dapat ditambahkan untuk melihat dari aspek teknis adalah terkait dengan metode pembuatan dan material.

\section{RAGAM HIAS SULUR GELUNG}

Ragam hias sulur gelung banyak ditemui pada ornamen-ornamen candi dan ukiran di beberapa masjid tua. Ragam hias ini merupakan konsep kosmogoni Hindu tentang penciptaan alam semesta. Perkembangan selanjutnya, terdapat beberapa ornamen masjid yang ditemukan menggunakan ragam hias sulur gelung. Konsep pemaknaan sulur gelung di candi berbeda dengan pemaknaan ragam hias di masjid. Proses pergeseran makna ini sangat menarik dikaji lebih jauh lagi.

F. D. K. Bosch (1960:42) menyebutkan bahwa inti ragam hias sulur gelung berawal dari bentuk padmamūla yang berbentuk permata simetris yang di dalamnya terdapat biji. Secara umum dapat dijelaskan bahwa bentuk ini adalah bagian dari akar lotus yang digambarkan dalam bentuk permata yang di dalamnya terdapat biji. Masing-masing tempat (candi dan masjid tua) memiliki beberapa variasi bentuk, misalnya di Candi Prambanan dan Masjid Mantingan memiliki bentuk menyerupai bulatan serta di Candi Kalasan memiliki bentuk seperti buah pir yang bagian atasnya terbuka.

Proses penciptaan alam semesta diawali dengan penciptaan air. Segalanya diawali dengan air, Brahman yang merupakaan esensi ketuhanan tertidur di atas air dalam wujud Vișnu yang disebut Narayana. Muncullah telur keemasaan dari air tersebut, kemudian melahirkan Brahma. Brahma disebut juga dengan nama Svayambhu, artinya terlahir dengan dirinya sendiri. Brahma memecahkan telur penciptaan menjadi dua bagian yaitu nirwana dan dunia. Telur keemasan sebagai awal mula kelahiran Brahma juga disebut hiranyagarbha. Hiranyagarbha melahirkan Vișnu yang memelihara, Brahma berwajah empat sebagai pencipta, dan Siva sebagai pelebur (Donder, 2007: 154-160).

Bentuk bulatan ini pada beberapa tempat juga mengalami perubahan bentuk menjadi semacam bejana yang dalam bahasa Sansekerta disebut kumbha. Isi bejana ini adalah air yang melambangkan kehidupan, regenerasi, kemewahan, dan kesuburan (F. D. K. Bosch 1960:112). Pengambilan tanaman teratai sebagai lambang kehidupan tampaknya menyatu dengan bentuk bejana yang dijadikan awal dari pergerakan bentuk ragam hias yang berupa sulur. Sulur adalah bentuk stilasi dari ornamen vegetal atau floral yang lazim digunakan pada pembuatan ragam hias.

Menurut Van der Hoop (1949:272), bahwa sulur tersebut sebenarnya adalah akar-akar teratai yang berada di bawah permukaan air yang pada 
buku-bukunya muncul daun yang berbentuk pilin. Gerakan sulur ini saling bergantian ke kiri dan ke kanan dengan ujung daun yang selalu mengikal terbalik dari gerakan sulurnya. Pola gerakan ini menjadi dasar pembuatan ragam hias yang berkembang di Jawa. Gerakan pilin-pilin ini sebenarnya merupakan dasar-dasar bentuk geometris pada ragam hias primitif.

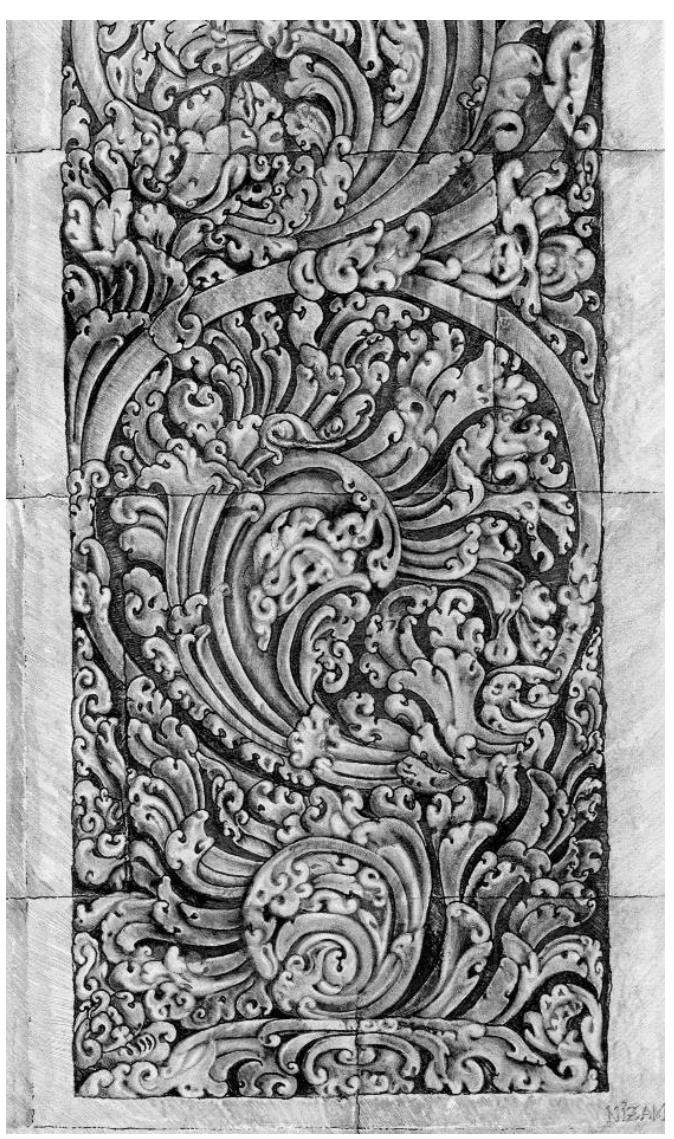

Gambar 1. Ragam Hias Sulur Gelung Candi Prambanan Untuk Ornamentasi Bidang Vertikal (Koleksi : Ahmad Nizam)

Ragam hias sulur gelung pada candi tidak hilang ketika masa Islam berkembang di Nusantara. Beberapa ornamen di masjid-masjid tua masih ditemukan ragam hias ini. Bentuk ragam hias ini mengalami evolusi bentuk yang disesuaikan dengan konsep Islam dalam memahami ornamentasi tempat ibadah. Ragam hias tersebut mengalami deformasi pada beberapa bagian. Prinsip dalam agama Islam menyebabkan beberapa pemahaman yang diekspresikan dalam bentuk ragam hias, antara lain bentuk modular, floral, dan simplifikasi.

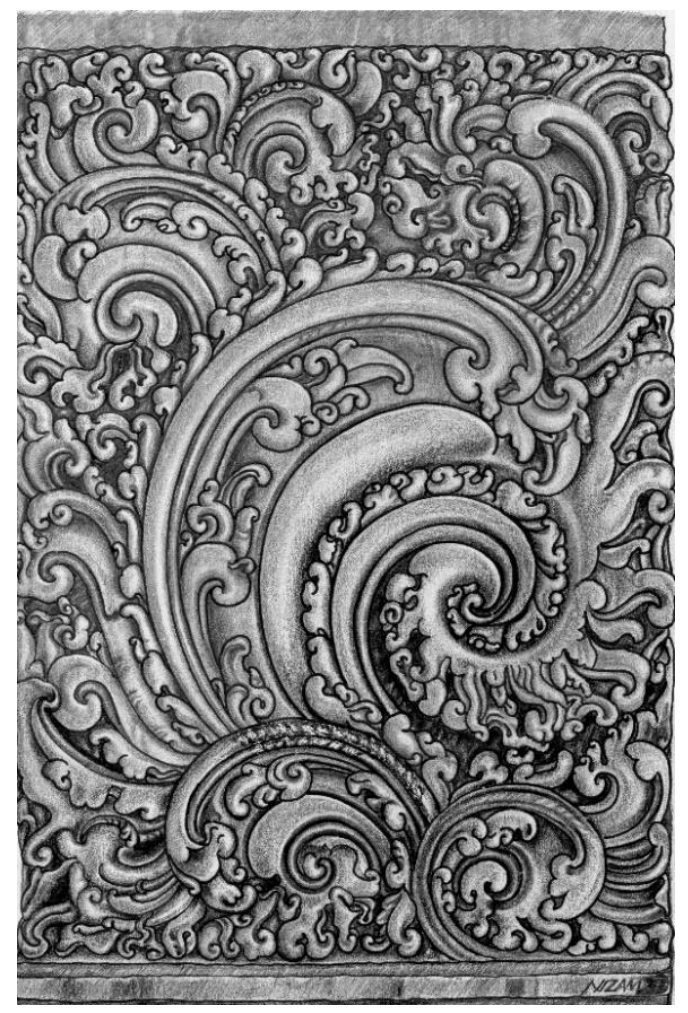

Gambar 2. Ragam Hias Sulur Gelung Masjid Demak Bagian Padmamula Sudah Dihilangkan (Koleksi : Ahmad Nizam)

\section{PRODUK KRIYA MASA KINI}

Seringkali pada dunia seni rupa, khususnya kriya, menghadapi persoalan yang seakan-akan kontradiktif antara persoalan pelestarian atau konservasi budaya dengan pemanfataan budaya dalam perspektif ekonomi. Pada tahap ini perlu dipertimbangkan secara komprehensif untuk mendapatkan solusi yang dapat dimengerti oleh pihak-pihak yang berkepentingan. Industri kreatif yang 
dikembangkan oleh beberapa negara saat ini memberikan acuan rantai nilai yang dimulai dari tahap kreasi, produksi, perlindungan, dan komersialisasi.

$$
\text { Kemajuan tingkat kehidupan }
$$

manusia semakin kompleks dengan berbagai macam variable penentu kesejahteraan manusia. Pada masyarakat yang hidup dalam era konsumsi, segala sesuatu kebutuhan dijadikan parameter simbolik dalam gaya hidup. Demikian pula dengan kriya, hasil-hasilnya sudah menjadi komoditas yang banyak memberikan nilai sosial ekonomi bagi masyarakat luas. Seringkali hasil kegiatan berkesenian dalam kriya disebut karya kriya maupun produk kriya. Biasanya karya kriya digunakan untuk menyebutkan bendabenda seni kriya yang memiliki bobot ekspresi lebih banyak jika dibandingkan dengan perannya sebagai komoditas ekonomi. Produk kriya banyak digunakan untuk menyebutkan benda-benda seni kriya yang lebih menitik beratkan sebagai komoditas ekonomi yang diperjualbelikan dalam transaksi jual beli. Beberapa pihak menyebutkan bahwa produk kriya sangat dekat dengan industri seni kriya.

Pasar global adalah pasar yang membutuhkan produk dan karya kriya untuk pemenuhan kebutuhan masa kini. Seakan-akan dunia pasar global tidak tersekat lagi dengan jarak dan waktu. Pasar global adalah bentuk dari perubahan pola konsumsi masyarakat. Baudrillad (2004:106) menyebutkan bahwa pembelian suatu barang tidak mesti didasrkan pada objek barang tersebut, melainkan perbedaan-perbedaan atas barang tersebut. Di dunia yang sangat moderen tumbuh kelas-kelas sosial yang memerlukan deferiasiansi konsumsi. Pasar dunia benar-benar memiliki segmentasi yang kompleks tergantung dari budaya dan lingkungan setempat. Kemewahan dalam suatu lingkungan tertentu belum tentu memiliki arti kemewahan bagi lingkungan lainnya. Para produsen memerlukan survey yang mendalam untuk mengetahui kemauan pasar yang berbeda dan cepat berubah.

Diskusi eksistensi kriya yang menghasilkan karya dan atau produk sangat terasa pada abad 19 dan 20, ketika dunia pada saat itu memasuki era industrialisasi. Terlepas dari diskusi tersebut, kriya mulai diproduksi seperti layaknya komoditas industri lainnya. Istilah desain mulai layak disebut dalam rangkaian produksi kriya, meskipun beberapa seniman kriya tradisional masih menggunakan metode-metode lama. Masing-masing metode memiliki segmentasi pasar yang berbeda satu dengan lainnya. Sebagai contoh topeng kayu di daerah Gunungkidul yang diproduksi dengan beberapa metode. Seniman tradisional yang membuat topeng gaya klasik masih menggunakan metode pengerjaan langsung pada material. Bentuk-bentuk topeng sudah melekat di pikiran seniman dan langsung dipahatkan pada material. Sementara untuk pembuatan topeng moderen, seringkali digunakan gambar dan tahapan perancangan layaknya produk-produk industri. Pada kasus ini, bentuk, ukuran, dan warna memiliki standar perhitungan yang sudah disepakati antara produsen dan konsumen (customer). 


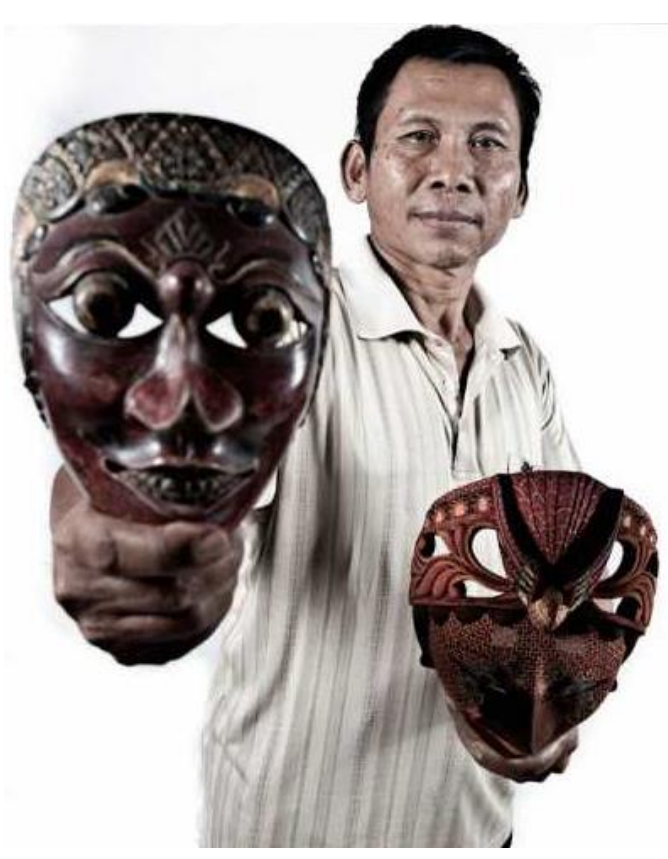

Gambar 3. Sujiman Seniman Topeng Gunungkidul Yang Membuat Topeng Tradisional Klasik Dan Mengembangkan Topeng Kayu Dengan Ornamentasi Batik (Sumber: katadata.co.id)

Kriya berkembang sesuai dengan kondisi zamannya, termasuk pada jenis karya, fungsi, makna, bentuk, dan art world-nya. Seniman sangat mungkin menggunakan kriya sebagai metode dan media ekspresi pribadi. Pada kasus ini seniman banyak menggunakan bentukbentuk simbolik yang dikomposisi dengan prinsip estetika. Masyarakat tradisional juga masih menggunakan karya-karya kriya untuk keperluan kelengkapan aktivitas budayanya, misalnya penggunaan busana untuk keperluan acara perkawinan adat. Pada masyarakat moderen, kriya digunakan untuk memenuhi kebutuhankebutuhan praktis tanpa dibebani batasan tradisi dan filosofi.

Ketika teknologi digital berkembang pesat, bisa jadi terdapat kolaborasi antara tenik kriya dengan pemanfaatan teknologi. Ini juga masih menjadi perdebatan dikalangan akademisi untuk mendefinisikan dan menjelaskan secara ilmiah dalam ranah keilmuan kriya. Teknologi digital tidak hanya difungsikan dalam proses dokumentasi saja, tetapi sedikit banyak telah masuk dalam proses kerja atau proses penciptaannya.

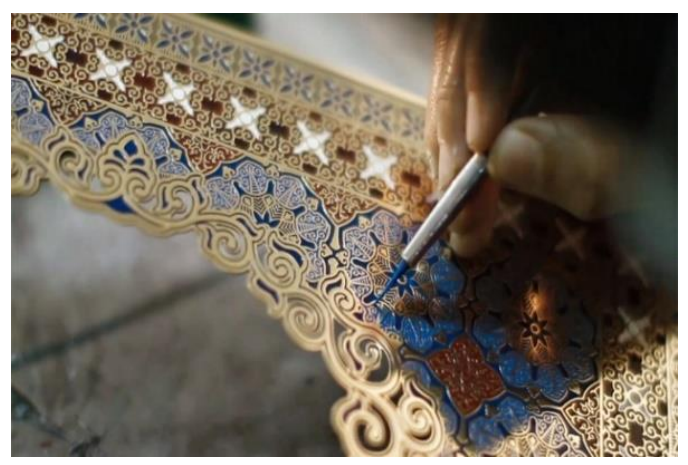

Gambar 4. Proses Pewarnaan Pada Ornamen Hasil Teknologi Digital Produk Perusahaan Kriya Nusantara (sumber : kriyanusantara.com)

Keberadaan metode tradisional
tidak serta merta hilang tergantikan
dengan teknologi moderen pada saat ini.
Masyarakat luas memaknai pada karya
kontemporer suatu kebebasan terhadap
penggunaan idiom dan metode tradisi
bahkan primitif. Konteks kekinian lebih
dikedepankan untuk memnuhi kebutuhan
praktis dan estetiknya.

Keberadaan metode tradisional tidak serta merta hilang tergantikan Masyarakat luas memaknai pada karya kontemporer suatu kebebasan terhadap penggunaan idiom dan metode tradisi bahkan primitif. Konteks kekinian lebih praktis dan estetiknya. 


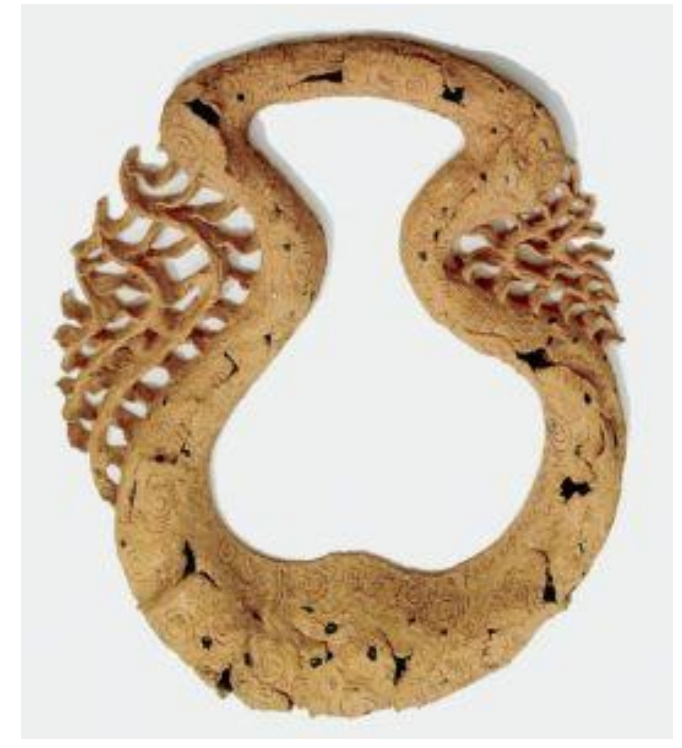

Gambar 5. Karya Kontemporer Noor Sudiyati Berjudul "Yin Yang" Diolah Menggunakan Tanah Liat Dengan Mengambil Idiom Keseimbangan Bangsa Timur Dan Teknik Tradisional Terakota (sumber : sahabat gallery.wordpress.com)

\section{STRATEGI PERANCANGAN PENERAPAN RAGAM HIAS SULUR GELUNG}

Tahap perancangan sering disebut dengan istilah "designing" secara sengaja maupun tidak sengaja merupakan tahapan yang pasti dilalui oleh kreator kriya. Pada masa lalu terutama pada pembuatan karya kriya tradisi proses perancangan menyatu dengan proses perwujudannya. Seorang empu keris akan membuat karyanya dengan tahapan meditasi untuk menenangkan diri dan memantapkan proses perancangannya. Semua tahapan penciptaan karyanya melekat dalam dirinya dan melebur menjadi satu kesatuan gerak sampai dengan terwujud dengan sempurna.

Pengaruh dunia industri sangat besar pada proses penciptaan kriya untuk tujuan-tujuan praktis dalam memenuhi kebutuhan manusia. Papanek (1973: 23) menyebutkan bahwa proses perancangan tidak dapat terlepas dengan aspek fungsi. Aspek fungsi tersebut meliputi metode, operasional penggunaan, asosiasi, telesis, estetik, dan kebutuhan. Interaksi antara alat, proses dan material merupakan keniscayaan dalam perancangan dan perwujudannya.

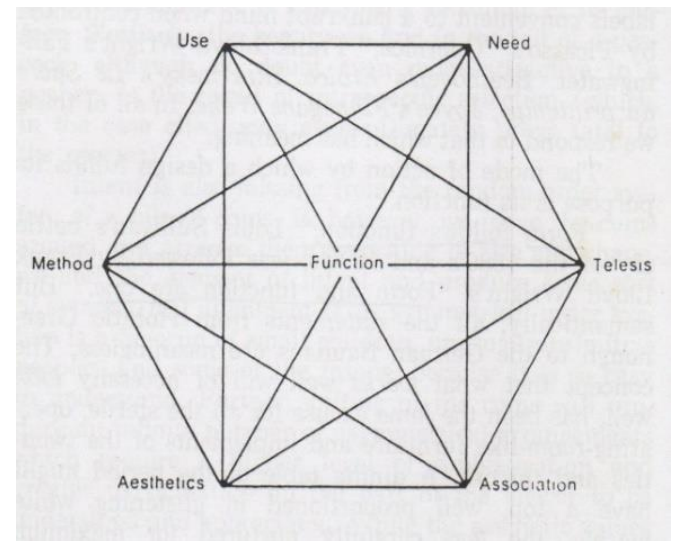

Gambar 6. Diagram Kompleks Fungsi (Sumber : Papanek, 1973: 26)

Dijelaskan oleh Christopher Jones (1979:75), strategi desain atau perancangan adalah menyusun tahapantahapan yang digunakan untuk mentransformasikan deskripsi ide menjadi perancangan akhir (final design). Metode perancangan yang digunakan untuk mengatasi problem-problem dalam perancangan itu sendiri disebut strategi. Secara garis besar terdapat dua kriteria dalam strategi perencanan, yaitu : (1) penentuan langkah-langkah persiapan (pre-planning) dan (2) penentuan pola.

Integrasi perancangan sangat diperlukan untuk mengoptimalkan hasil, ini dapat dilakukan pada metode tradisonal maupun moderen. Tujuan penciptaan karya menjadi acuan utama dalam perancangan. Tujuan diintegrasikan dengan beberapa aspek, yaitu (1) objek 
penciptaan, (2) pengguna, (3) fungsi, (4) nilai-nilai, (5) lingkungan, (6) produksi, (7) distribusi, (8) regulasi, dan (9) komersialisasi.

Khusus pada perancangan motif, perlu dipertimbangkan penyusunan elemen visual dengan prinsip seni. Balldinger (1967: 26-40) menyebutkan bahwa pencapaian bentuk dapat dipertimbangkan dengan membuat interelasi antara keseimbangan, penekanan, irama, dan proporsi. Beberapa pekerjaan seni lebih mengedepankan intuisi untuk memperoleh keharmonisan bentuk dengan pertimbangan prinsip seni pad pengkomposisian elemen visual.

Pada kasus penerapan sulur gelung, telah diperoleh data visual dari observasi langsung objek atau artefak pada candi dan masjid. Beberapa artefak menunjukkan bahwa tekah terjadi kerusakan ringan sampai berat yang menyebabkan ketidakjelasan bentuk aslinya. Tahap pertama dalam perancangan ini adalah merekreasi elemen visual berupa garis, tekstur, bidang, dan volume ragam hias dengan metode visual tracing. Peranan fotografi sangat diperlukan untuk mencapai presisi bentuknya. Tahap kedua adalah penggambaran ulang untuk memperjelas objek visual dan menjadi acuan utama dalam perancangan. Tahap ketiga dilakukan pendalaman konsep dengan merujuk beberapa referensi pendukung dan wawancara kepada orang yang memiliki kompetensi. Ktiga tahap tersebut memiliki peran sebagai data yang akan dianalisis menjadi bentuk baru yang disesuaikan dengan tujuan pembuatan karya.
Salah satu metode deformasi ragam hias yang digunakan adalah simplisitas (penyederhanaan bentuk) dengan mengambil beberapa unsur yang dianggap mendukung hasil akhirnya, contoh langkah ini dapat dilihat pada gambar di bawah.

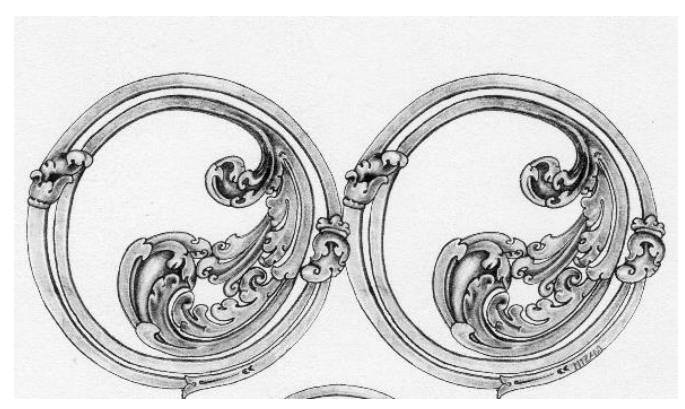

Gambar 7. Ragam Hias Sulur Gelung Dikembangkan Menjadi Ornamen Arah Horisontal

(Koleksi : Ahmad Nizam)

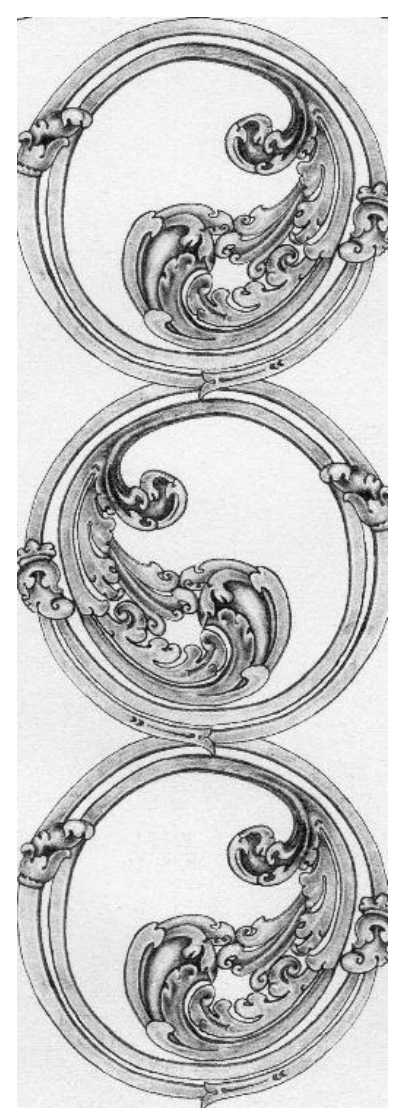

Gambar 8. Ragam Hias Sulur Gelung Dikembangkan Menjadi Ornamen Arah Vertikal (Koleksi : Ahmad Nizam) 


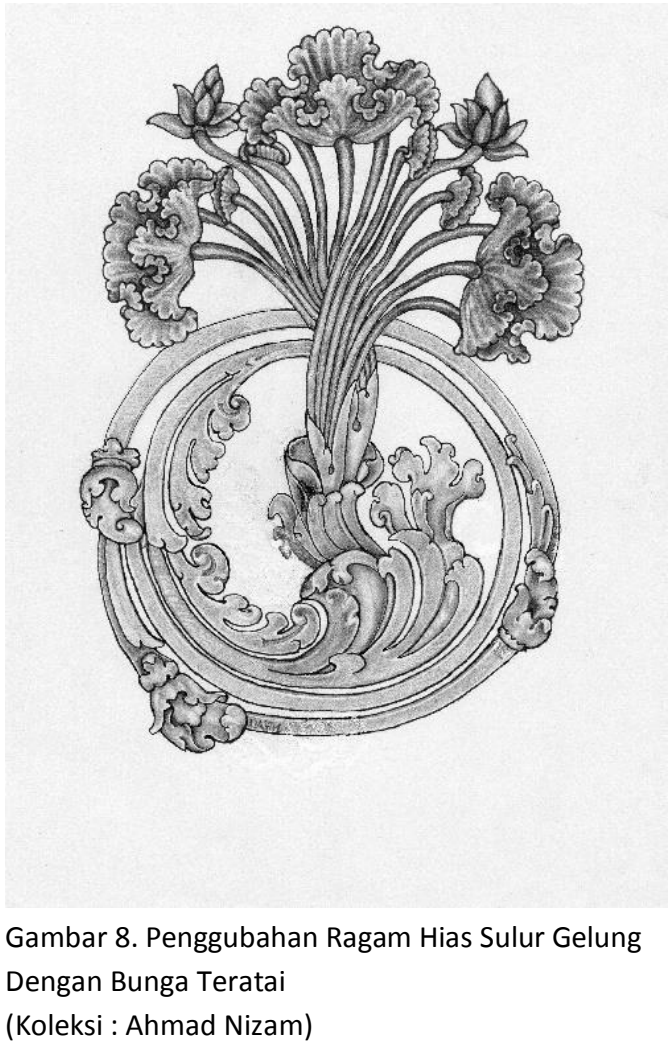

PENUTUP

Indonesia banyak memiliki warisan budaya berupa artefak estetik yang tersebar pada banyak bangunan tradisional. Kekayaan ini perlu dilestarikan dan dikembangkan agar dapat memberikan penguatan pada identitas bangsa dan meningkatkan kesejahteraan. Keduanya dapat berjalan beriringan tanpa mengorbankan salah satu diantaranya.

Dalam dunia seni rupa dikenal proses perancangan untuk optimalisasi hasil. Namun istilah ini pada seniman tradisional kriya sering melebur menjadi satu kesatuan gerak dalam penciptaannya. Dewasa ini, terutama pada era yang penuh dengan kompetisi, diperlukan strategi dan metode yang tepat untuk melakukan perubahan dalam dunia kriya. Tuntutan seperti ini tidak terelakkan lagi karena kemajuan teknologi juga terjadi dalam segala lini kehidupan. Teknologi perlu dimanfaatkan agar eksistensi kriya tetap pada konstelasi yang kompetitif.

\section{DAFTAR PUSTAKA}

Baldinger, Wallace S., The Visual Arts, Oregon: University of Oregon, 1967.

Budrillad, Jean P., La Societe de Consummation (diterjemahkan Wahyunto dalam judul : Masyarakat Konsumsi) , Kreasi Wacana: Yogyakarta, 2004.

Bosch, F. D. K., De Gouden Kiem : Inleiding In De Indische Symboliek, Amsterdam-Brussel: Uietgeversmaatschaappij Elsevier, 1948.

Donder, I Ketut, Kosmologi Hindu: Penciptaan, Pemeliharaan, dan Peleburan Serta Penciptaan Kemabli Alam Semesta, Surabaya: Paramita, 2007.

Hoop, van Der A. N. J. Th., Indonesiche Stermotiven, Ragam Hias Indonesia, Indonesian Ornamental Design, Batavia: Koninkluk Bataviaasch Genootschap van Kunsten en Wetenschaappen, 1949.

Jones, Christopher J., Design Methods: Seeds of Human Futures, London: John Wiley \& Sons Ltd., 1979

Papanek, Victor, Design for the Real World, New York: Bantam Books, 1973. 